\title{
ILLUMINATION AS THE DESIGN STRATEGY ELEMENT
}

Monika Štiklica ${ }^{1}$

UDK: 628.974 .8

DOI: $10.14415 /$ konferencijaGFS2019.083

Summary: Design strategy as the phenomenon of the modern era of architectural planning and interior design has been little explored so far and rarely used as the phase preceding the postulate of the project concept. The goal of this project is to emphasize the illumination role in postulating the design strategy, as well as set forth essential recommendations in the design of specific environments.

Key words: Design strategy, design, illumination, color.

\section{INTRODUCTION}

Design strategy should be viewed as the initial framework of the project explaining what to design and why, rather than how to do it.

Design is both art and science in one, shaping our environment wherever we are, making it the surface of the environment which we create, while the very word "strategy" refers to the general plan, a set of actions directed to establishing distinct, clearly defined goals. Design strategy applies the principles of the traditional design and places them into a "broader" picture, redefines the way to approach the problem, identifies the possibilities to act upon and helps in bringing more complete and, above all, more stable solutions.

If we integrate the design process and the design way of thinking into the bigger goals, for example the business goals of our clients, we raise the concept of design to the level of the strategic instrument that can boost the business itself. The design strategy is primarely used as the method in the design of public and business facilities intended to yield profit to the investor.

Furthermore, if we pose the design strategy as the instrument to achieve as much functional and comfortable living space, without profit as the goal of design, but for the sake of designing the space that suits the user, we can count on achieving success.

The design strategy should include the following questions:

- What are the existing problems and challenges?

- Which benefits and breakthroughs should be used?

- What are the user needs that have not been met so far?

- $\quad$ Has there been a change in attitude and behavior of clients/consumers/users?

- $\quad$ Which new trends and new ideas can appear?

\footnotetext{
${ }^{1}$ Monika Štiklica, dipl.arh., University of Novi Sad, Faculty of Civil Engineering Subotica, Kozaračka 2a, Subotica, Serbia, tel: ++381 62238 228, e-mail: studio@monikastiklica.com
} 
Савремена достигнућа у грађевинарству 23-24. април 2019. Суботица, СРБИЈА

If we look at the evolutionary flow of a project (Figure 1), we can deduce that the design strategy is involved in the very business part of the creation process already at the very beginning, while the design itself comes no sooner than in the sixth stage of the business process. What we must take into consideration and understand as the vital factor is the market exploration which tells us how the overall business strategy and likewise the design strategy should be formed relative to the wishes and needs of the end user.

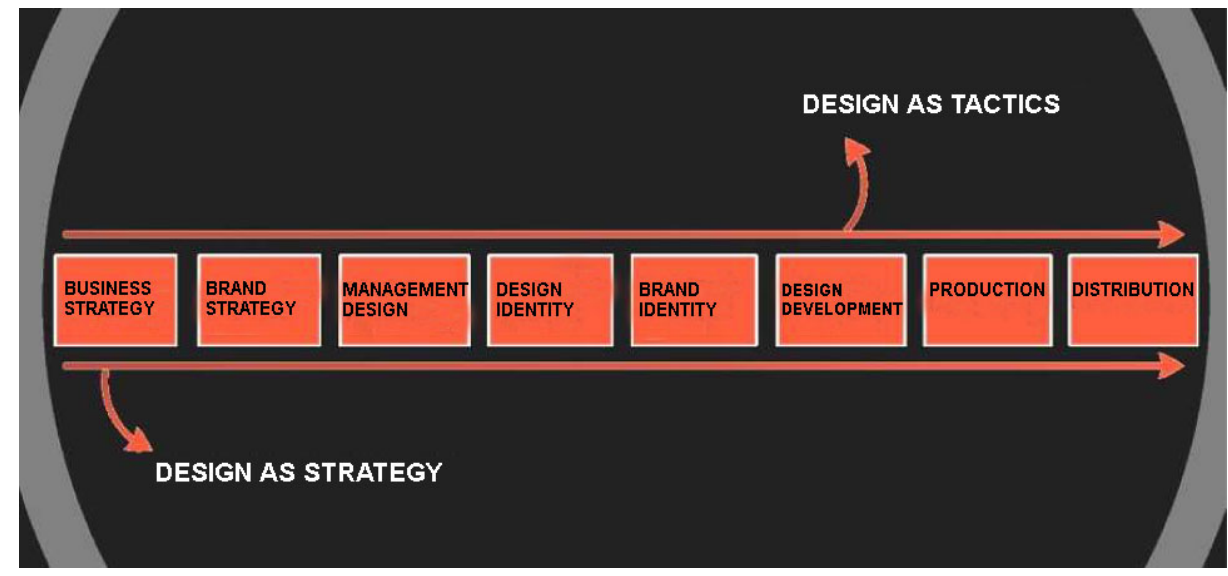

Figure 1 Evolutionary flow of a project

In short, the goal of the design strategy is to clarify the feasible and sustainable vision, to discover threats and possibilities through exploration, to establish how to measure success in time, to point out how your project fits into the ecosystem, to propose the plan to how to achieve something and finally how to add to and improve the product strategy, the business strategy.

As architects, designers, we must be aware of the fact that the use of particular illumination in a given space represents the important element in the creation of a certain atmosphere. Thus, we can further conclude that illumination is one of the the most important factors in establishing the very design strategy of the space being designed.

\section{COLOR AND LIGHT CORRELATION}

Strictly speaking, the entire visual aspect owes its existence to brightness and color. The limits defining the shape of an object derive from the capability of eyes to differentiate surfaces of various brightness and color. This is even true of the lines defining shape in drawings, they are visible only when only when Indian ink is different by the paper color. However, if we tried to put together the alphabet of thirty colors instead of shapes, we would see that that system is unusable. The number of colors that we can easily and reliably discern barely exceeds six, in particular three primary and three secondary colors 
Contemporary achievements in civil engineering 23-24. April 2019. Subotica, SERBIA

connecting them, though the standard color systems contain several hundreds of tones. 2 We are quite sensitive in differentiating finely distinct nuances, but when we need to recognize a particular color by memory or at a certain spatial remoteness from another, our discerning powers are strictly limited.

The differences in degree are much harder to remember than differences in type. The four color dimensions that we can reliably differentiate are redness, blueness, yellowness and a palette of grays, while when we have to differentiate purple from violate, we will be certain only when we place them next to each other.

Color consistencies are also aided by the phisiological fact that retina adjusts to the given illumination. As the sensitivity to light automaticaly reduces when eyes are looking at a very bright spot, likewise various kinds of color receptors adjust their reactions selectively when one particolar color dominates the field of view. When they encounter green light, eyes reduce its reaction to green. An artist's colors are very much at the mercy of the prevailing light, while it has little influence to his shapes. Matis once said:” If drawing belongs to the realm of the Spirit and color to that of the Senses, you must draw first to cultivate the Spirit and to be able to lead color through the paths of the Spirit ". 3 Through him speaks the tradition afferming that the shape is more important and dignified than color. With such views in mind, it by no means wonder that the shape is identified with traditional virtues of male gender, while colors are identified with female seductiveness. According to Charles Blanc " The union of drawing and color is necessary to engender painting, just as the union of man and woman to engender humanity; but drawing must maintain supremacy over color. If it is otherwise, painting will be on the road to ruin; painting will be undone by color as humanity was undone by Eve ".4

The scientists say that the color is a subjective perception which is fulfilled only when the following three conditions are met: there exists the observer, there exists the object and there exists enough light in order to perceive things from the visible spectrum. If there was not enough light, the entire world would be painted in gray shades.

Brightness of a surface can depend on the following: strength of the light source, the angle at which the light falls to the surface, the structure of the matter the surface is built of, i.e. its capability to reflect greater or lesser amount of light and the distance of the surface from the eye of the beholder.

All this speaks in favor of the fact that we cannot observe the color and illumination separately, but rather we have to regard the correlation between these two elements which have to be in harmony.

Colors and light interact with each other in creating the mood. Dark colors can be emphasized making the room visually smaller, but at same time can contribute to the feeling of greater intimacy. Brighter colors tend to stand out making the space look bigger. Pastel tones help the user to relax more than in the presence of basic colors.

2 Arnheim R. (1941) Art and Visual Perception - A Psychology of the Creative Eye, Page 281 3 Arnheim R. (1941) Art and Visual Perception - A Psychology of the Creative Eye, Page 284 4 Arnheim R. (1941) Art and Visual Perception - A Psychology of the Creative Eye, Page 285 


\section{LIGHT CHARACTERISTICS}

Human eye can bear a wide range of light variations from 0.001 lux to 10000 lux, which corresponds to the strength of the sun on white snow. Broadsheets are usually read at about 0.2 lux. 5 The use of natural light is always desirable. This saves money, has a desirable psychological effect and enables reliable color differentiation. Even distribution of light and protection therefrom must be adequately allocated. Majority of living species requires $600-700$ lux light in order to develop and live normally. In spaces with lower light that this, green plants lose color.6 Local light sources can be used to add to the general illumination, while plants should be positioned to have sufficient light supply.

\begin{tabular}{|c|c|c|}
\hline CONDITIONS & DESIGN PROVISIONS & APPLICATION \\
\hline $\begin{array}{lrr}\text { Light } & \text { adjustment } & \text { from } \\
\text { stronger } & \text { to weaker } & \end{array}$ & It takes 30 seconds to illuminate & $\begin{array}{l}\text { Enters- from outer daily } \\
\text { light to artificial light, } \\
\text { service- from kitchen to the } \\
\text { restaurant }\end{array}$ \\
\hline $\begin{array}{l}\text { Light adjustment } \text { from } \\
\text { weaker to stronger }\end{array}$ & It takes 30 seconds to dim & $\begin{array}{l}\text { Enters-night illumination } \\
\text { to brighter interiors }\end{array}$ \\
\hline $\begin{array}{l}\text { Contrast between the bright } \\
\text { areas and the background }\end{array}$ & $\begin{array}{l}\text { 2:1- barely noticeable } \\
\text { 10:1- significant } \\
\text { 100:1- dominant }\end{array}$ & $\begin{array}{l}\text { For exposure, attractions. } \\
\text { Gradual amplification } \\
\text { above the cash registers } \\
\text { and bars }\end{array}$ \\
\hline $\begin{array}{l}\text { Flash, successive contrast } \\
\text { causes unpleasantness or } \\
\text { interferes with visibility }\end{array}$ & $\begin{array}{l}\text { Flash index: } \\
\text { 10- critical } \\
\text { 19- good measure } \\
\text { 28- general measure } \\
\end{array}$ & $\begin{array}{l}\text { Avoids reflection } \\
\text { shiny surfaces }\end{array}$ \\
\hline $\begin{array}{l}\text { Light intensity depending on } \\
\text { space and visual } \\
\text { requirements }\end{array}$ & $\begin{array}{l}\text { Entrance:200 lux -20Lm/m2 } \\
\text { Staircases :200 lux -20Lm/m2 } \\
\text { Halls:100lux-10Lm/m2 } \\
\text { Restaurant:50-100lux,5-10Lm/m2 } \\
\text { Coffee shop:150lux-15Lm/m2 } \\
\text { Kitchen:300lux-30Lm/m2 }\end{array}$ & $\begin{array}{l}\text { Special applications: } \\
\text { Cash registers, bars:400lux } \\
\text { Tables:200lux } \\
\text { Shows, exibitions:500lux }\end{array}$ \\
\hline $\begin{array}{l}\text { Reduction of light on } \\
\text { account of the age of the } \\
\text { person in the room }\end{array}$ & $\begin{array}{r}\text { Age: } 40-10 \% \text { loss } \\
60-25 \% \text { loss }\end{array}$ & $\begin{array}{l}\text { Special situations, hospitals } \\
\text { and other public } \\
\text { institutions }\end{array}$ \\
\hline Field of view & $\begin{array}{l}\text { Narrow field } 2 \text { " for details } \\
\text { Closer view of } 30 " \text { and more to } \\
\text { observe objects in perspective }\end{array}$ & $\begin{array}{l}\text { Signs, information, } \\
\text { markings of windows, } \\
\text { pieces of furniture, } \\
\text { everything that should be } \\
\text { noted }\end{array}$ \\
\hline
\end{tabular}

Table 1 The table features necessary quantities of illumination in certain rooms. 7

Light consideration should precede all other causes of visual perception, for without light eyes cannot observe neither shape, nor color, nor space, not even motion. Even

5 Carl Gardner and Raphael Molony,2001, Light Re-interpreting Architecture, str.127

6 Edition 2002, Transparency and Feeling, Edition Schott, str 56.

7 Carl Gardner and Raphael Molony,2001, Ligth Re-interpreting Architecture, str 141. 
Contemporary achievements in civil engineering 23-24. April 2019. Subotica, SERBIA

psychologically, it remains one of the most fundamental and strongest human perceptions. It is the visual counterpart of the other vital force, warmth. According to the Book of Genesis, creation of light gave the first day, while the sun, the moon and the stars were added not before the third day.

The discrepancy between physical and perceptive facts is revealed when we try to answer the question: How bright are things? We cannot explain the facts talking about the "permanence" of brightness, certainly not in the sense of asserting that objects are seen "as bright as they really are ". The brightness we see depends, in a complex way, on the light distribution in the overall situation. It depends on the processes in the eyes of the beholder, as well as the physical ability of the object to absorb and maintain the light it receives. That physical capability is called luminance or reflectance. 8 Depending on the light strength, one object can reflect more or less light, but its luminance, i.e. percentage of light it reflects, remains the same. A piece of black velvet absorbing a lot of light it receives can, under strong light, reflect back the same amount of light as a poorly lit piece of silk that reflects the most of energy.

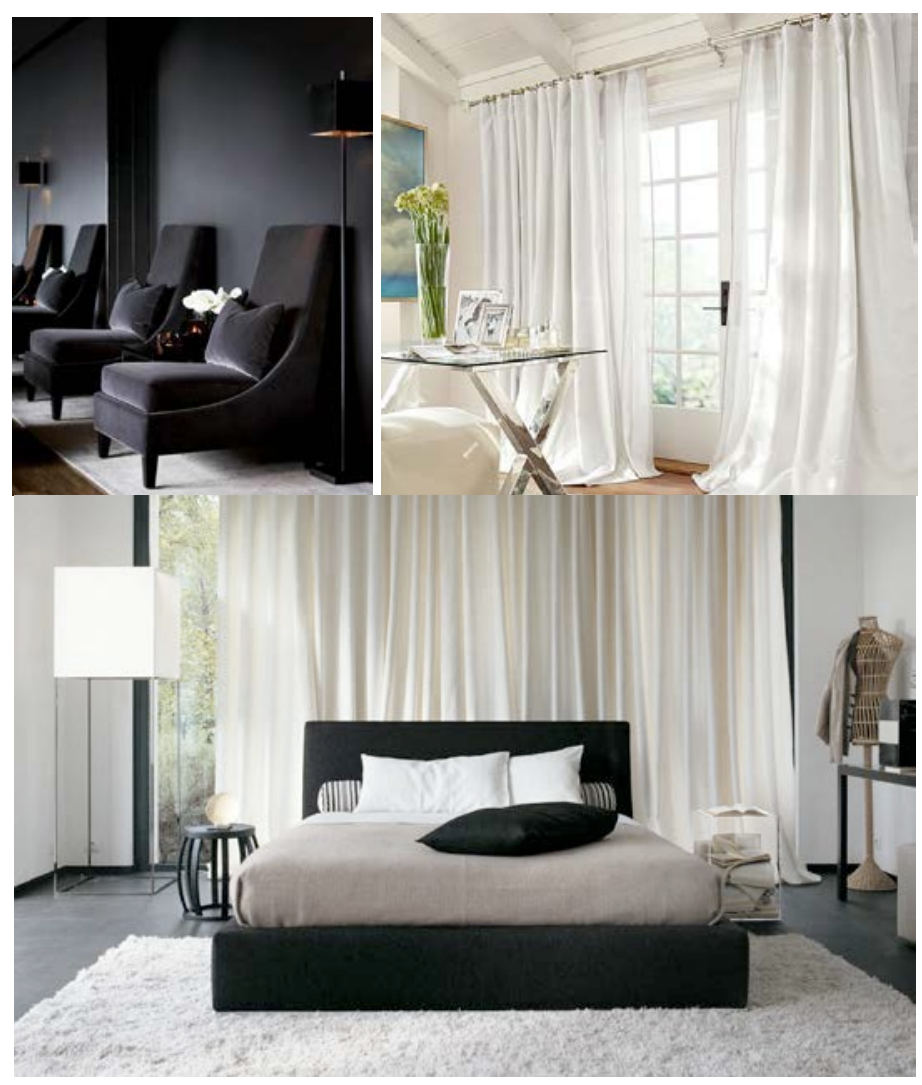

Figures 1, 2, 3 Examples of illuminance and reflectance of materials relative to the color and light

8 Arnheim R. (1941) Art and Visual Perception - A Psychology of the Creative Eye, Page 259 
Савремена достигнућа у грађевинарству 23-24. април 2019. Суботица, СРБИЈА

Relative brightness of an object is most reliably perceived when the entire room is exposed to equal light.

In such conditions, the nerve system can consider the illumination level permanent and simply ascribe each object the brightness it indicates in the entire range spanning from the dimmest to the brightest object in the room. It is very important, however, that such mechanism acts quite good even when the light is not equal, but rather moves, for example, from being very bright close to the light source to the dark shadow. When a room has walls with windows in them painted a shade brighter than those affected by the daily light, simple impression of illumination is partly compensated and the brightness of the room seems more even, which can have a soothing or disturbing effect on the observer, depending on whether he or she tends to ignore or regard the world outside the window. The term "illumination" is not clear in itself. At the first thought might be that the illumination must be present whenever we see something, for if the light does not fall on the object, it remains invisible. Equally illuminated object does not show any signs of receiving its light from another side.9

The cast shadows interfere with the pure analogy between the light and the spatial orientation because they can dim a surface that would otherwise be bright, as well as the reflections illuminating dark spots.

Shadows can be either bound to the object or cast. The former lie on the very object and are created by the shape, spatial orientation and remoteness of the object from the light source. The cast shadows fall from one object to another or from one part of the same object to another.

\section{THE ROLE OF COLORS AND ILLUMINATION IN POSING THE DESIGN STRATEGY}

In order to describe the difference in the application of colors and illumination, we will use examples in fast food restaurants and hotel lobbies.

Fast service restaurants use bright colors and uncomfortable chairs to insure that the guest does not stay longer than 20 minutes which is the time it takes to finish the meal and give the seat to the next customer. The design strategy of such restaurants is reflected in the fact that there should be a quick exchange of guests during the day in order to increase consumption and secure as many visitors. In this type of restaurant one should not use architectural elements with a view of creating a pleasant environment in which a user wishes to remain longer than necessary. Therefore, we make sure that this objective is achieved by using strong lights, vivid colors and uncomfortable equipment.

9 Arnheim R. (1941) Art and Visual Perception - A Psychology of the Creative Eye, Page 262 
Contemporary achievements in civil engineering 23-24. April 2019. Subotica, SERBIA
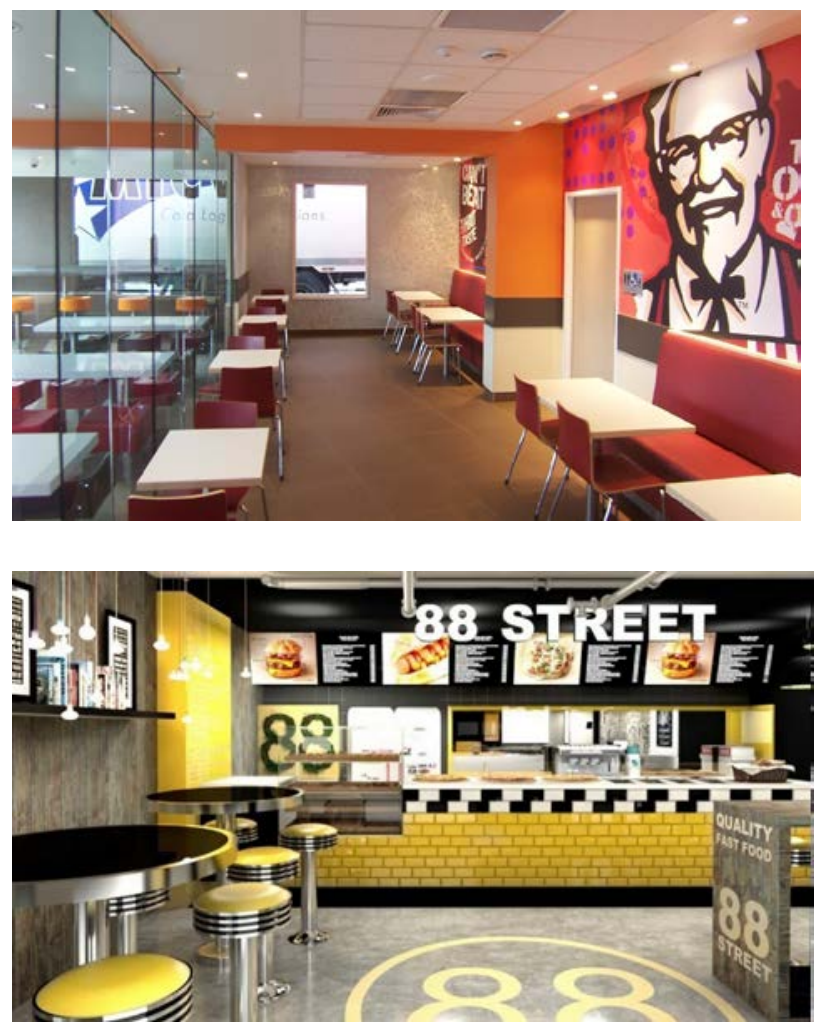

Figures 4 and 5 Colors and illumination in fast food restaurants

On the other hand, hotel lobbies are designed with a view to having the user wish to remain longer as well as having him go back to the place where he or she acquired a good sense of intimacy, relaxedness and comfort. The same design strategy is applied by luxurious restaurants aimed at having the guest feel comfortable to make sure that he or she spends as much time in the space and take the feeling of comfort in order to wish to go back to the same place. 
7. МЕЂУНАРОДНА КОНФЕРЕНЦИЈА

Савремена достигнућа у грађевинарству 23-24. април 2019. Суботица, СРБИЈА
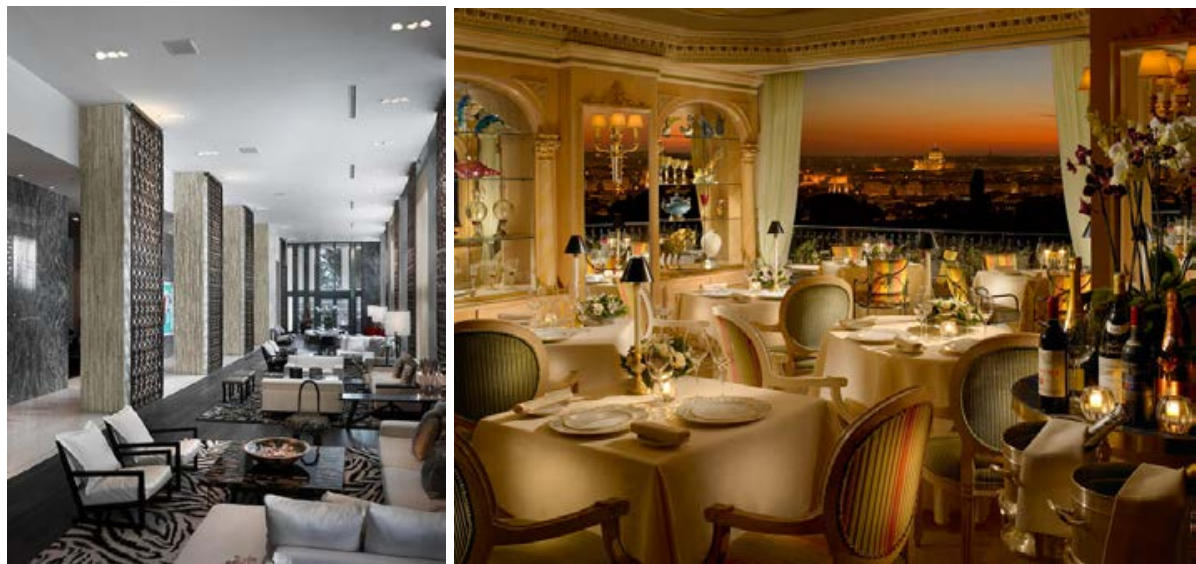

Figures 6 and 7 Colors and illumination in hotels and luxurious restaurants

Artificial illumination (relative to natural) is an architectural tool that is easier to apply and requires less skill and effort to obtain the desired result (Figure 23 and 24).

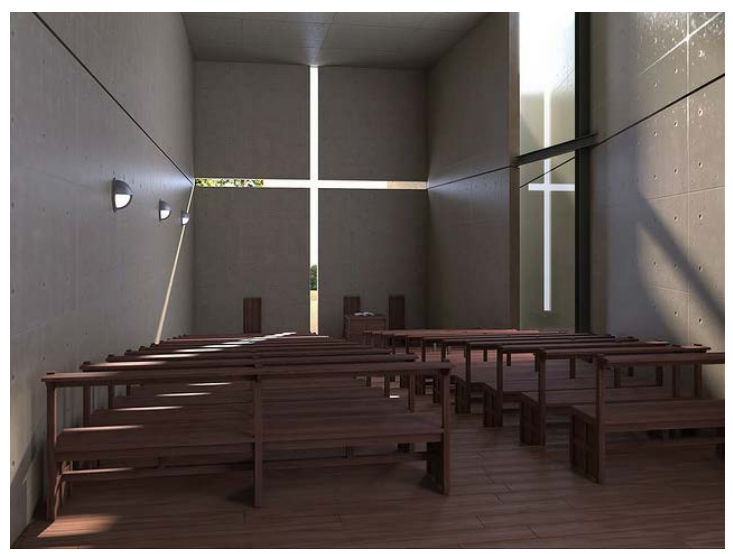

Figure 8 The use of natural illumination, Ibaraki Kasugaoka Kyokai Church, architect Tadao Ando, Osaka, Japan 
Contemporary achievements in civil engineering 23-24. April 2019. Subotica, SERBIA
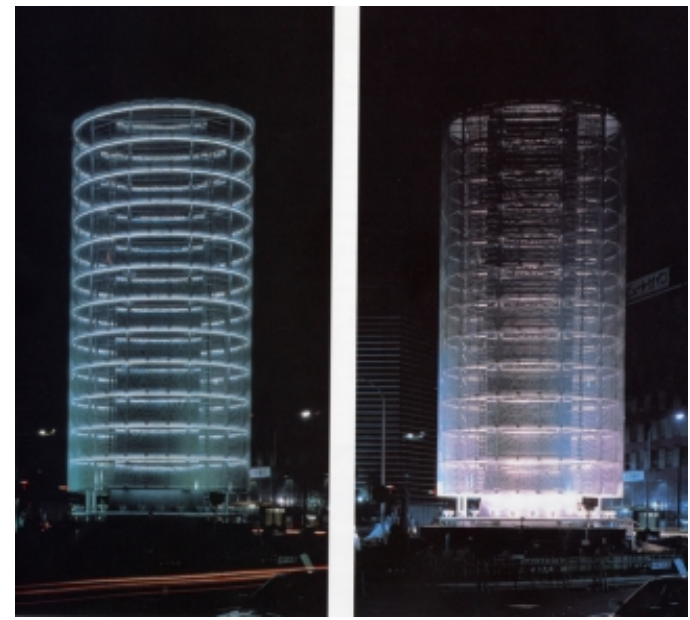

Figure 9 The use of artificial illumination, Yokahoma Tower of wind

\section{CONCLUSION}

The role of light in architecture is an inexhaustible subject in the sense of possibilities the use of this element offers in formation and realization of certain ideas. The use of light and achieving the desired effect with the application of appropriate shaping and design is a very complex subject matter and requires one to delve seriously in the very phenomenon. Therefore, the messages thus sent through the object are more difficult to read from the aspect of their deeper meaning, but the visual effects generated are easier to grasp.

When we apply illumination in architectural objects for the purpose of creating a certain environment aimed at meeting the needs of a particular group of users and achieving a business success, we deal with a particular need of an architectural element as a tool for posing a design strategy. With proper utilization of this and any other architectural or design element, we pose an object designed for the purpose of meeting users' needs and inevitably come to the conclusion that this way success as well as the permanence of the solution are secured.

\section{REFERENCES}

[1] Arnheim R. (1941) Art and Visual Perception - A Psychology of the Creative Eye 1941

[2] Carl Gardner and Raphael Molony,2001, Ligth Re-interpreting Architecture, 2001

[3] Edition 2002, Transparency and Feeling, Edition Schott, 2002.

[4] Carl Gardner and Raphael Molony, Light Re-interpreting Architecture, 2001

[5] Neufert E., Bauenwurfslehre 1936 